\title{
PENGEMBANGAN ALAT TANAM JAGUNG TIPE TUGAL DALAM UNTUK LAHAN KRITIS
}

\section{DEVELOPMENT OF A DEEP TUGAL TYPE CORN PLANTER FOR CRITICAL LAND}

\author{
Makbul Hajad ${ }^{1}$ Radi $^{1 凶}$, Bambang Purwantana ${ }^{1}$ \\ ${ }^{1}$ Departemen Teknik Pertanian dan Biosistem, Fakultas Teknologi Pertanian, Universitas Gadjah Mada \\ $\bowtie$ Komunikasi Penulis, email: radi-tep@ugm.ac.id \\ DOI:http://dx.doi.org/10.23960/jtep-l.v10i2.129-138
}

Naskah ini diterima pada 2 Februari 2021; revisi pada 23 Februari 2021; disetujui untuk dipublikasikan pada 8 April 2021

\begin{abstract}
Blora and Grobogan are regions with higher production capacity of corn commodity compared to other regions in Central Java province. However, low number of technical irrigation and el-nino phenomenon have become the main threat for the sustainability of corn farming in both regions. During dry session, the top soil of the land are solidified which lead to higher difficulty for planting the corn seed using traditional tool. An improved design of the traditional seeder is then required to solve this problem to enable farmers plant corn seed during dry session. The objective of this research was to develop seeder prototype with "Tugal Dalam" type in Blora and Grobogan regions where the land have been categorized as marginal land during dry session. The proposed design is based on technical, ergonomic, economical, and social aspect. The qualitative approach was used to obtain the technical, ergonomical, economical and social aspect required by the farmer. Kansei Engineering is used to translate and evaluate the proposed design through some tests conducted on several group of farmers where they were requested to use 4 seeder design options and write their preference on each design option based on the mentioned aspects. Tests confirmed that the proposed design can be used to plant a corn seed at farmers desired characteristics. Kansei engineering also confirmed that 'high speed', 'easy to operate', 'low price', 'easy to handle' and 'has a watering system' were preferred by the farmers and determined their decision on buying and using the seeder tool
\end{abstract}

Keywords: kansei engineering, marginal land, seeder development, tugal dalam

\begin{abstract}
ABSTRAK
Blora dan Grobogan merupakan daerah penghasil komoditas jagung dengan kapasitas produksi yang lebih tinggi dibandingkan dengan daerah lainnya di Provinsi Jawa Tengah. Tetapi, minimnya jumlah irigasi teknis dan phenomena el-nino menjadi ancaman yang perlu mendapat perhatian untuk keberlangsungan pertanian jagung di kedua daerah. Selama musim kemarau, lapisan permukaan tanah mengeras sehingga penanaman benih jagung menggunakan alat tradisional menjadi kurang efektif. Sehingga, pengembangan alat tanam diperlukan untuk membantu petani menanam benih jagung di musim kemarau. Tujuan dari penelitian ini adalah untuk mengembangkan alat tanam tipe tugal dalam untuk menanam benih jagung di daerah Grobogan dan Blora yang mengalami kekeringan di musim kemarau. Prototipe desain dikembangkan berdasarkan aspek teknis, ergonomis, ekonomi dan sosial budaya petani. Pendekatan kualitatif digunakan untuk mendapatkan persyaratan teknis, ergonomis, ekonomi dan sosial budaya yang diinginkan petani pada desain alat untuk penanaman di musim kemarau. Kansei engineering digunakan untuk mengevaluasi desain yang diajukan dan mendapatkan karakteristik desain yang diinginkan petani untuk alat tanam. Pengujian laboratorium menunjukkan bahwa alat tanam dapat digunakan untuk menanam benih jagung dengan persyaratan teknis yang diinginkan. Kansei engineering menunjukkan bahwa faktor kecepatan penggunaan, penggunaan yang mudah, harga yang terjangkau, ringan ketika dibawa, dan memiliki kotak air adalah beberapa karakteristik yang diinginkan petani untuk desain alat tanam benih pada musim kemarau.
\end{abstract}

Kata Kunci: kansei engineering, lahan kritis, pengembangan alat tanam, tugal dalam 


\section{PENDAHULUAN}

Provinsi Jawa Tengah merupakan salah satu sentra produksi jagung di Indonesia dengan jumlah produksi mencapai $12.3 \%$ produksi nasional dan menempatkan Kabupaten Grobogan dan Blora menjadi daerah dengan kapasitas produksi tertinggi. Dari data BPS Jawa Tengah, produksi jagung pada tahun 2018 Kabupaten Grobogan mencapai 770.349 ton dan kabupaten Blora mencapai 362.118 ton (BPS, 2018). Dari data yang ada, terlihat adanya trend kenaikan yang signifikan dari tahun ke tahun. Hal ini didukung oleh karakteristik lahan yang subur dan kondisi iklim yang sesuai dengan kebutuhan budidaya jagung (Sunanto, 2013). Lahan pertanian di daerah Grobogan dan Blora didominasi oleh jenis tanah berlempung yang merupakan faktor utama komoditas jagung dapat tumbuh subur dengan hasil yang baik (Ritung, et al., 2010). Hal ini menjadi faktor pendukung petani di daerah Grobogan dan Blora mampu menanam komoditas jagung hampir sepanjang tahun baik pada musim tanam (MT)1, MT2 maupun MT3. Komoditas jagung juga dibudidayakan petani baik di lahan sawah, tegalan maupun pada beberapa lahan di kawasan perhutani. Sehingga, dapat dikatakan bahwa komoditas jagung merupakan salah satu faktor yang sangat menentukan bagi roda perekonomian daerah maupun kesejahteraan petani di Kabupaten Grobogan dan Blora.

Tanaman jagung merupakan tanaman dengan tingkat penggunaan air sedang, berkisar antara 400-500 mm (FAO, 2001). Sehingga, kesuksesan budidaya jagung membutuhkam ketersediaan air dalam jumlah dan waktu yang tepat.
Kebutuhan air pada tahap penanaman juga sangat penting untuk mengoptimalkan proses perkecambahan, kekurangan air pada saat masa tanam akan menyebabkan benih terlambat tumbuh bahkan gagal tumbuh karena kekurangan sumber nutrisi (Smith, 1990). Faktanya, hampir $79 \%$ areal pertanaman jagung di Indonesia terdapat di lahan kering, dan sisanya $11 \%$ dan $10 \%$ masing-masing pada lahan sawah beririgasi dan lahan sawah tadah hujan (Harimurti, 2018). Artinya, budidaya tanaman jagung yang dilakukan oleh petani adalah mayoritas pada musim kemarau, dimana ketersediaan air minim. Dari data, diketahui bahwa sebagian besar lahan pertanian di daerah Grobogan (53\%) dan Blora (68\%) merupakan lahan tadah hujan dan hanya sebagian kecilnya saja yang sudah dilengkapi dengan irigasi teknis (BPS, 2018). Sehingga, budidaya jagung di wilayah Grobogan dan Blora dapat dikatakan sangat bergantung pada ketersediaan air untuk kebutuhan pengairan lahan. Ketergantungan pada ketersediaan air ini juga dapat dilihat dari data produksi jagung di Kabupaten Grobogan yang mengalami penurunan pada tahun 2018 saat terjadi penomena el-nino di hampir seluruh wilayah Indonesia.

Pada musim kemarau, tingginya laju evaporasi air tanah menyebabkan lapisan permukaan lahan mengeras, sehingga menyebabkan proses penanaman menggunakan metode tradisional seperti alat tugal kayu akan sangat sulit. Akan tetapi, walaupun terjadi pengerasan pada lapisan permukaan tanah, lapisan di bagian bawah permukaan tanah berpotensi masih lembab dan memungkinkan untuk dilakukan penanaman jagung. Dari informasi yang telah dihimpun,

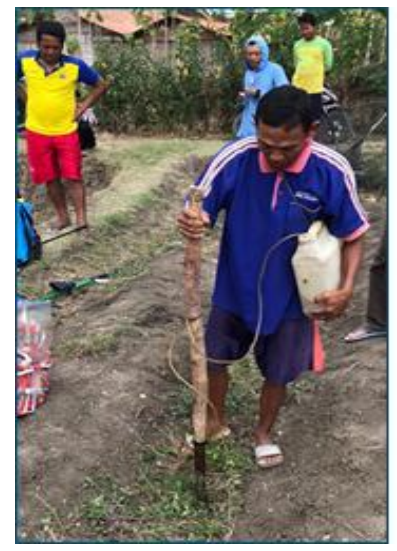

Gambar 1. Penggunaan Alat Tanam Tugal Dalam dengan Kotak Air 
beberapa petani mampu mengoptimalkan penanaman jagung di lahan mereka pada musim kemarau dimana permukaan tanah telah mengeras. Petani memodifikasi alat tugal yang mereka miliki dengan memberikan implemen berupa balok besi pada ujung tugal yang memungkinkan petani menanam lebih dalam dari biasanya $(>10 \mathrm{~cm})$ dan dilengkapi dengan kotak air (Gambar 1). Hal ini mengindikasikan bahwa peningkatan kapasitas produksi jagung di Kabupaten Grobogan dan Blora masih mungkin untuk dilakukan menggunakan alat tanam yang tepat guna sehingga petani dapat tetap produktif. Namun, desain alat tanam yang telah dibuat petani ini perlu dikaji lebih lanjut secara akademis sehingga diperoleh prototipe alat tanam benih jagung tepat guna yang optimal dari sisi teknis, ergonomis, ekonomi dan sosial budaya petani. Kajian pengembangan prototipe alat tanam yang efektif untuk penanaman jagung di lahan minim irigasi seperti di Kabupaten Grobogan dan Blora perlu dipertimbangkan untuk meningkatkan kapasitas produksi jagung di tingkat petani. Desain alat harus sesuai dengan kebutuhan teknis lahan setempat, memenuhi aspek ergonomis dan dengan nilai ekonomi yang terjangkau untuk meningkatkan penerimaan petani pada desain alat yang ditawarkan dan mendukung introduksi alat tanam yang lebih efisien untuk pertanian jagung.

Beberapa alternatif desain alat tanam jagung telah tersedia di pasaran untuk menanam benih jagung seperti tugal semi-mekanis (tipe hentakan), tipe dorong manual, tipe dorong dengan motor penggerak, dan alat tanam mekanis dengan traktor. Tidak hanya itu, beberapa tipe rancangan alat tanam jagung juga telah dikembangkan untuk meningkatkan efektivitas penanaman benih jagung. Syafa'at dan Subantoro (2017) mengembangkan alat tanam benih tepat guna yang dapat digunakan untuk menanam berbagai benih komoditas palawija

\section{BAHAN DAN METODE}

Menurut Kosky, et al., (2010) untuk pengembangan desain produk yang optimal, proses perancangan sekurang-kurangnya melibatkan 4 tahapan proses, seperti: (1) pendefinisian masalah dan penetapan alternative,
(2) Pembuatan desain, (3) konstruksi dan pengujian, dan (4) tahap evaluasi. Tahap pendefinisian masalah ditujukan untuk memperoleh persyaratan teknis dan ergonomis dari alat yang akan dikembangkan serta untuk menetapkan opsi desain yang reliable untuk permasalahan yang dihadapi. Feasibility study digunakan untuk mengumpulkan informasi terkait karakteristik teknis desain alat yang dibutuhkan. Tahap pembuatan desain adalah tahapan untuk merealisasikan opsi yang telah diambil berupa model 3D sehingga diperoleh gambaran nyata dari alat yang akan dikembangkan. Tahapan Konstruksi dan Pengujian dimaksudkan untuk merealisasikan model 3D yang telah dibuat melalui tahapan perbengkelan dan pengujian laboratorium maupun lapangan untuk mengetahui performa dari rancangan. Tahapan evaluasi dimaksudkan untuk merangkum hasil pengujian yang telah dilakukan dan menetapkan perbaikan pada draft rancangan yang dibuat sebelum ditetapkan menjadi prototipe akhir dari sebuah rancangan produk.

Perancangan prototipe alat tanam tugal dalam ini dilakukan melalui beberapa tahapan (Gambar 2) yang meliputi: (1) tahapan feasibility study, (2) tahapan desain dan fabrikasi, (3) tahapan pengujian laboratorium dan lapangan, serta (4) evaluasi menggunakan kansei engineering.

\subsection{Tahapan Feasibility Study (FS)}

Kajian FS ini dilakukan untuk memperoleh data primer dari lokasi target terkait persayaratan teknis dan ekonomi alat yang dibutuhkan oleh petani. Data yang dihimpun berupa data primer dan sekunder terkait: (1) spesifikasi alat tanam eksisting, (2) Spesifikasi benih yang ditanam, (3) karakteristik lahan di lokasi target dan (4) analisis usaha tani (AUT) jagung di lokasi target. Data ini kemudian digunakan sebagai dasar dalam pembuatan desain prototipe awal alat yang disesuaikan dengan karakteristik pengguna, lahan dan benih jagung yang yang akan ditanam, serta disesuaikan dengan kemampuan ekonomi petani untuk membeli alat.

Kajian FS ini menggunakan dua metode untuk menghimpun data yaitu metode kuesioner dan pengujian lapangan. Melalui metode kuesioner, ada beberapa informasi yang dihimpun seperti: 
(1) teknik dan alat tanam benih yang digunakan petani, (2) desain dan spesifikasi alat tugal yang dimiliki petani, (3) metode pemberian air awal yang diterapkan petani, (4) harga alat tanam yang dimiliki petani, (5) penerimaan petani pada alat tanam tipe tugal dalam dengan pemberi air, (6) harga alat tanam yang mau dibayarkan petani untuk alat tugal dalam, (7) analisis usaha tani. Metode kuesioner ini menggunakan wawancara langsung dengan proporsional random sampling di kabupaten Blora dan Grobogan. Jumlah sampel ditetapkan sebanyak 90 sampel secara proporsional untuk Kabupaten Grobogan dan Blora karena data terkait jumlah petani jagung yang melakukan budidaya pada lahan kritis tidak diketahui secara pasti. Proporsi sampel dibagi berdasarkan: (1) total luasan petak sawah yang digarap, (2) topografi, dan (3) wilayah administrative. Pada pengujian lapangan, dilakukan pengujian pada aspek kekerasan tanah dan karakteristik benih yang ditanam petani.

\subsection{Tahap Desain dan Fabrikasi}

Setelah memperoleh data terkait persyaratan teknis dan ekonomi alat tanam yang dibutuhkan, tahapan selanjutnya adalah membuat draft prototipe dari alat tanam. Draft prototipe dibuat menggunakan software solidwork untuk menampilkan model secara 3D. Dimensi alat didasarkan pada data dimensi alat tanam yang digunakan petani. Dimensi kotak benih dan lubang outlet benih ditetapkan berdasarkan dimensi dan karakteristik benih yang ditanam petani. Pemilihan dan penetapan material didasarkan pada aspek teknis kebutuhan alat tanam dan kondisi lahan yang menjadi target lokasi. Detail variabel yang diberikan pada alat seperti penggunaan pedal, penambahan kotak air, dan tuas didasarkan pada preferensi desain yang diinginkan oleh petani. Selanjutnya, tahapan fabrikasi dilakukan di Laboratorium Energi Dan Mesin Pertanian, Departemen Teknik Pertanian dan Biosistem, Fakultas Teknologi Pertanian, Universitas Gadjah Mada.

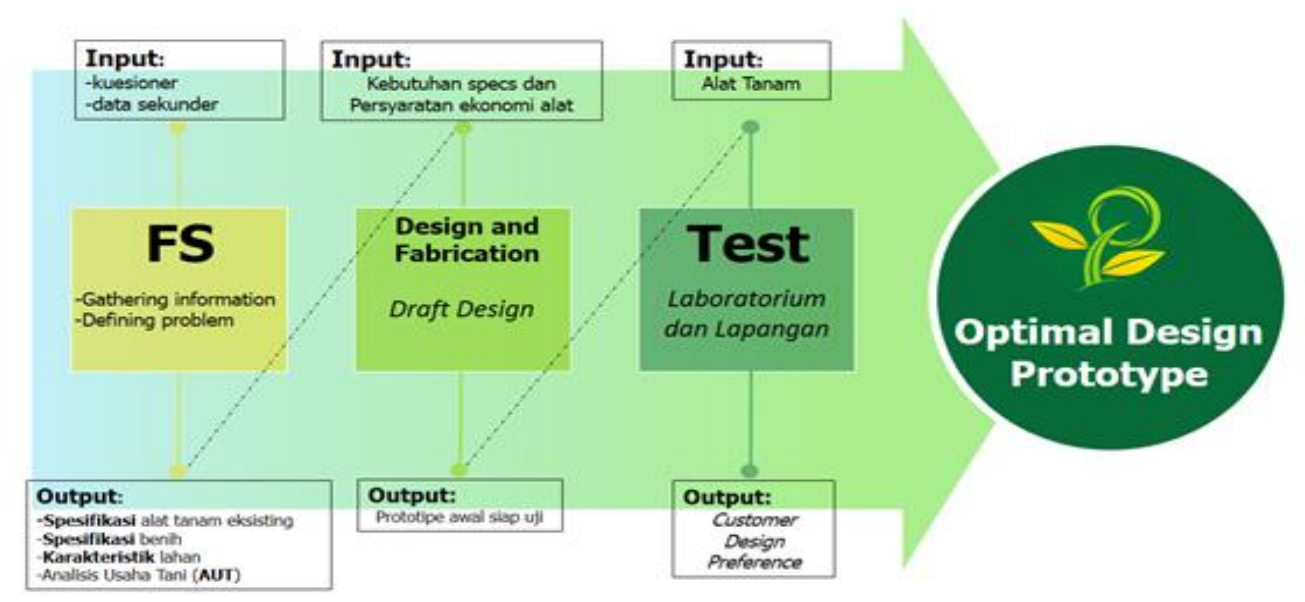

Gambar 2. Konsep Pengembangan Alat Tanam Jagung Tipe Tugal Dalam

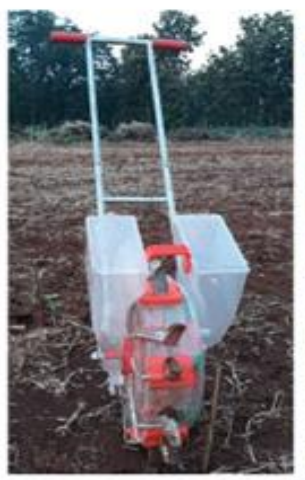

(a)

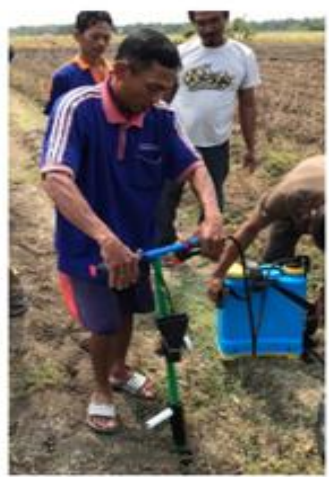

(b)

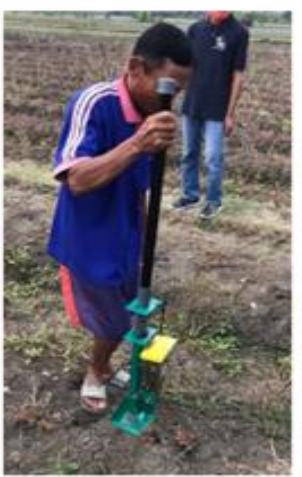

(c)

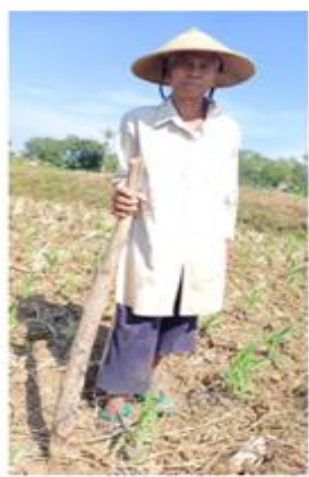

(d)

Gambar 3. Desain Alat Tanam yang Diujikan: (a) Tugal Tipe Dorong, (b) Tugal dengan Hooper, (c) Tugal Dalam dengan Hooper dan Pemberi Air, dan (d) Tugal Kayu (Milik Petani) 


\subsection{Tahap Pengujian}

Setelah alat difabrikasi, ada dua pengujian yang dilakukan: (1) Pengujian Laboratorium dan (2) Pengujian Lapangan. Pengujian laboratorium dilakukan untuk menguji apakah sistem pengungkit yang dibuat dapat bekerja dengan baik dan kedalaman tanam maksimum yang dapat dicapai menggunakan alat. Pengujian Lapangan dilakukan untuk menguji performance dari prototipe alat di lokasi target. Ada 4 opsi desain alat tanam yang dibawa (gambar 3) : (1) alat tanam tipe dorong, (2) alat tanam dengan hooper, (3) alat tanam dengan hooper dan kotak air, dan (4) alat tugal manual dengan kayu. Pengujian lapangan ini difokuskan untuk mendapatkan feedback dari petani terkait draft desain yang ditawarkan. Setiap petani diminta untuk menggunakan masing-masing opsi desain untuk menanam benih jagung di lahan yang mereka miliki. Setelah itu, petani diminta untuk memberikan penilaian pada masing-masing opsi desain alat.

\subsection{Kansei Engineering (KE)}

Kansei Engineering (KE) adalah salah satu metode yang dapat digunakan untuk meningkatkan kepuasan pengguna pada produk yang ditawarkan. Kansei enginnering digunakan untuk menerjemahkan preferensi yang dipersyaratkan oleh calon pengguna pada produk yang akan dikembangkan (Jindo dan Hirasago, 1997). Pada penelitian ini, Kansei Engineering digunakan untuk mendapatkan preferensi desain yang diinginkan oleh petani sebagai calon user. Pendekatan ini digunakan untuk meningkatkan dan mempercepat adaptasi petani pada alat sehingga introduksi alat tanam yang lebih efisien untuk menanam benih jagung dapat dilakukan untuk mengganti cara tanam tradisional. Pada penelitian ini, preferensi desain dari petani yang digali meliputi aspek fungsionalitas, aspek efektivitas dan ergonomi serta ekonomi. Petani diminta untuk memberikan penilaian pada ke empat opsi desain yang ditawarkan dan memberikan kesan terkait kelebihan dan kekurangan masing-masing opsi desain.

\section{HASIL DAN PEMBAHASAN}

\subsection{Spesifikasi Alat Tanam yang Dibutuhkan}

Pada kajian FS yang dilakukan, proporsi sampel dibuat berdasarkan wilayah administrative, luas lahan yang digarap dan topografi dari lahan garapan. Dari data yang diperoleh (Gambar 4), sampel pada penelitian ini menunjukkan angka yang cukup proporsional dan mewakili kondisi populasi. Dari data yang diperoleh, diketahui bahwa sebagian besar responden berpendidikan SD, SMA dan SMP dan hanya sebagian kecil yang menempuh pendidikan sarjana. Dari sisi usia, mayoritas responden berada pada rentang usia di atas 40 tahun. Tentu, tingkat pendidikan dan usia akan sangat berpengaruh pada respon yang diberikan pada penelitian ini terutama dari sisi pengenalan dan penerimaan pada teknologi baru (Gambar 5).

Dari data yang diperoleh, seluruh petani (100\%) menggunakan tugal kayu untuk melakukan penanaman benih jagung. Pertama, petani membuat lubang menggunakan tugal dengan kedalaman 5-7 cm, kemudian benih jagung diletakkan di dalam lubang dan ditutupi dengan

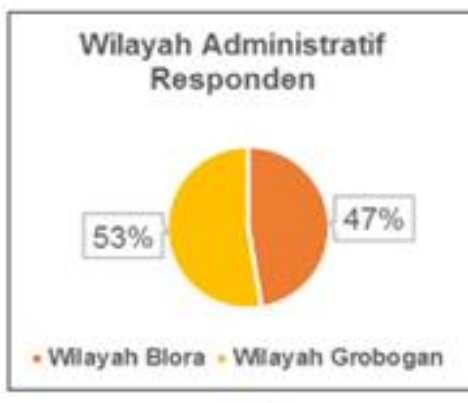

(a)

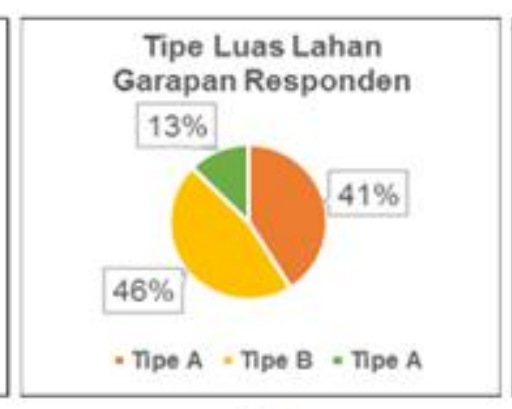

(b)

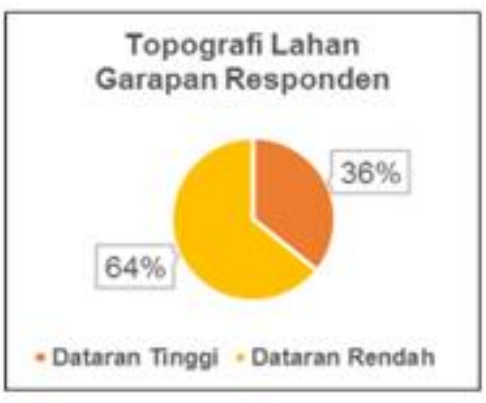

(c)

Gambar 4. Proporsi Sample Berdasarkan: (a) Wilayah Administratif, (b) Tipe Luas Lahan Garapan, dan (c) Topograpi Lahan Garapan Responden 
pupuk kandang. Kedua, pada setiap lubang diberikan pengairan awal sekitar 180-220 mL untuk membantu proses perkecambahan. Pemberian air awal dilakukan petani dengan menggunakan kendi atau jerigen plastik dimana setiap lubang tanam diberikan air secukupnya. Persyaratan lainnya, diusahakan setiap lubang dapat terisi hanya $1 \mathrm{biji} /$ perlubang untuk perkembangan tanaman yang optimal. Harga alat tanam yang dimiliki petani tidak lebih dari Rp. 50.000 ,- karena biasanya petani membuat sendiri tugal kayu dengan bahan seadanya.

Dari sisi kendala pertanian, $56 \%$ petani mengaku terkendala pada sisi ketersediaan air, 32\% terkait jamur dan hama penyakit, $13 \%$ terkait kekerasan tanah di musim kemarau dan 9\% terkait tidak efektifnya alat tanam di musim kemarau (Gambar 6). Mayoritas petani (59\%) merespon baik terkait konsep alat tanam yang dilengkapi dengan hooper benih dan kotak air dengan alasan akan dapat melakukan proses penanaman lebih efektif. Namun tantangannya adalah terkait harga, dimana hanya $14 \%$ responden yang mengaku mau membayar lebih dari Rp. 50.000,- untuk membeli alat tanam dengan hooper benih dan kotak air. Sehingga, alat tanam yang didesain harus memperhatikan baik aspek teknis maupun aspek ekonomi terutama harga dari alat. Dari hasil analisis usaha tani, diketahui bahwa rerata margin hasil usaha tani pertanian jagung di kabupaten Blora dan Grobogan adalah Rp. 101,751 (seratus satu ribu tujuh ratus lima puluh satu rupiah) per $100 \mathrm{~m}^{2}$ luasan lahan petani. Artinya, jika luasan garapan misalkan 5,000 $\mathrm{m}^{2}$, maka margin usaha tani pertanian jagung hanya mencapai mencapai Rp. 5,087,550 untuk 90-100 hari masa tanam. Hal ini mengindikasikan bahwa nilai perekonomian dari pertanian jagung masih relative minim.

Dari hasil pengukuran terhadap kekerasan permukaan tanah di daerah Grobogan dan Blora, diperoleh data bahwa kekerasan tanah di musim kemarau (MT2) masih bervariatif dari 40 - 120 $\mathrm{N} / \mathrm{cm}^{2}$ (Tabel 1). Hal ini mengindikasikan bahwa lapisan permukaan tanah pada beberapa lokasi memang mengalami pengerasan yang dapat menyulitkan petani untuk melakukan penanaman benih jagung pada musim kemarau.

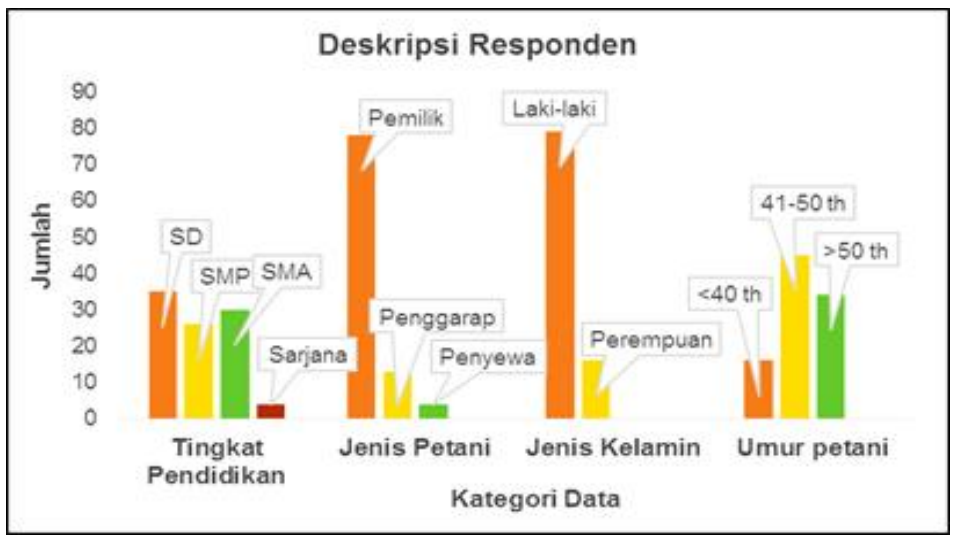

Gambar 5. Deskripsi Tentang Responden

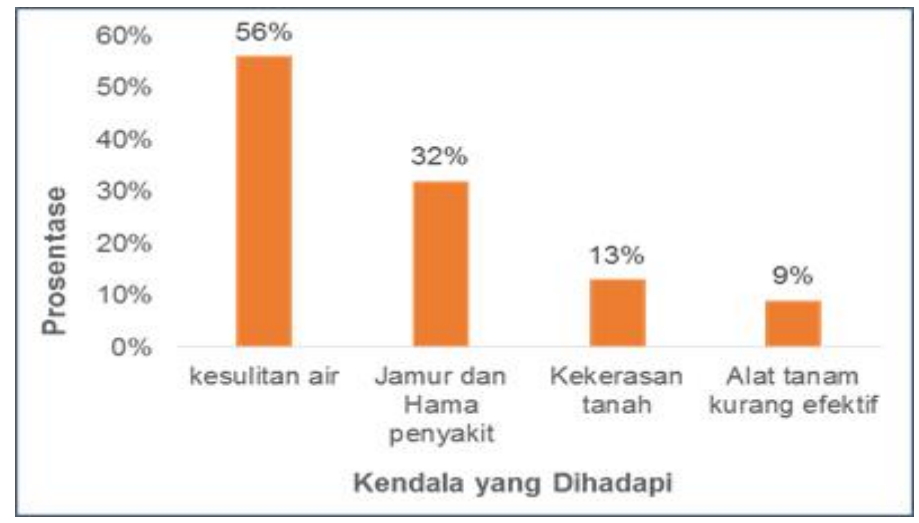

Gambar 6. Kendala Pertanian Jagung di Musim Kemarau 
Alat tugal yang dimiliki petani terbuat dari kayu yang satu sisinya diruncingkan untuk membantu penetrasi alat ke dalam tanah ketika pembuatan lubang tanam. Alat ini dibuat dengan panjang $110-120 \mathrm{~cm}$ dengan berat $3-4 \mathrm{~kg}$, diameter $5-8$ $\mathrm{cm}$, dan kedalaman tanam 6-8 $\mathrm{cm}$. Mayoritas petani menggunakan benih jenis hibrida dengan panjang rerata 7.65-12 $\mathrm{mm}$ dan lebar 7.25-9.30 $\mathrm{mm}$. Pengukuran dimensi alat tugal dan benih ini digunakan untuk mendesain kedalaman alat tugal yang nantinya akan dikembangkan. Dari informasi diatas, untuk permasalahan tanah yang relative kritis/keras, kedalaman alat tugal yang dibutuhkan adalah $15-20 \mathrm{~cm}$ yang dilengkapi dengan hooper dengan ukuran outlet sebesar 12-14 mm, dilengkapi dengan pemberi air yang dapat memberikan pengairan per lubang tanam sebesar 180-220 mL/lubang tanam, dan memungkinkan alat untuk menanam $1 \mathrm{biji} / \mathrm{lubang}$ tanam.

\subsection{Rancangan Prototipe Awal Alat Tanam Tipe Tugal Dalam}

Setelah diperoleh informasi terkait kebutuhan teknis alat, setelah itu dilakukan perancangan dan fabrikasi alat tanam jagung tipe tugal dalam. Dalam perancangan, aspek kebutuhan teknis, ergonimis, dan sosial budaya masyarakat menjadi pertimbangan. Selain itu, aspek teknis dan ekonomis dijadikan dasar dalam menentukan penggunaan material. Rancangan prototipe awal dari alat tanam benih jagung tipe tugal dalam dapat dilihat pada Gambar 7.

\subsection{Pengujian Laboratorium dan Lapangan} Pengujian laboratorium dilakukan untuk mengetahui apakah alat dapat berfungsi sesuai dengan yang diharapkan. Dari pengujian labortorium dihasilkan bahwa prototipe awal ini dapat menanam sampai kedalaman $15-20 \mathrm{~cm}$ dengan 1 benih/lubang tanam dan pemberian air sekitar 200-220 mL/lubang tanam. Sehingga, dapat disimpulkan bahwa prototipe awal ini memenuhi spesifikasi teknis untuk digunakan menanam benih jagung di lahan kritis minim irigasi. Selain pengujian laboratorium, dilakukakan pula pengujian lapangan di lokasi target (Kabupaten Grobogan dan Blora) (Gambar 8). Pengujian lapangan ini lebih difokuskan untuk mendapatkan respon dari petani terhadap prototipe awal yang diberikan. Alat tugal ini dioperasikan dengan cara: tugal ditancapkan pada tanah, injak tuas penekan untuk menambah kedalaman lubang tanam yang diinginkan, lepas

Tabel 1. Hasil Pengukuran Kekerasan Tanah

\begin{tabular}{cccc}
\hline No & Kabupaten & Lokasi & Kekerasan Tanah $\mathbf{~ N} / \mathbf{c m}^{\mathbf{2}} \mathbf{)}$ \\
\hline 1 & \multirow{3}{*}{ Grobogan } & Pulokulon & $45-52$ \\
2 & & Tawangharjo & $37-44$ \\
3 & & Bandungan & $41-90$ \\
\hline 4 & \multirow{2}{*}{ Blora } & Tunjungan & $85-120$ \\
5 & & Todanan & $72-86$ \\
\hline
\end{tabular}

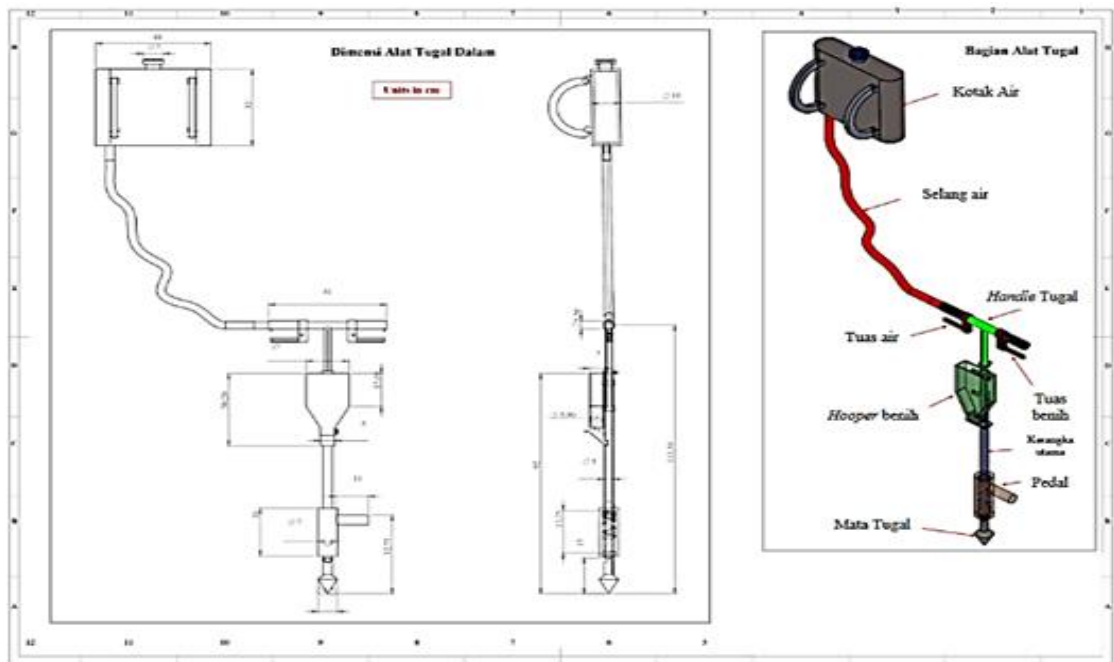

Gambar 7. Prototipe Awal Tugal Dalam dengan Hooper Benih dan Kotak Air 
pijakan hingga tuas penekan terangkat, tekan tuas pengatur benih, tekan tuas pengatur air, angkat tugal tersebut. Benih jagung dan air akan masuk dalam lubang tanam yg dibuat. Ketinggian tugal bisa diatur sehingga alat dapat digunakan secara ergonomis sesuai dengan ketinggian operator. Alat tugal ini dapat diatur menyesuaikan dengan kebutuhan jumlah benih yang akan ditanam per lubang dengan mengganti bagian penakar benih yang bersesuaian. Laju air disetting $60 \mathrm{~mL} /$ detik sehingga untuk memberikan pengairan 180-220 mL/lubang dibutuhkan penekanan handle selama 3-4 detik.

Pada pengujian lapangan ini, ada 4 opsi desain alat tanam jagung dibawa yaitu alat tanam tipe dorong, alat tanam dengan hooper benih, alat tanam dengan hooper benih dan kotak air (prototipe awal), serta alat tugal kayu. Uji coba di lakukan dengan 4 kelompok tani di daerah Blora dan Grobogan dengan jumlah responden 65 orang. Sebelum petani diberikan kesempatan untuk mencoba masing-masing opsi desain, petani diberikan arahan terkait bagaimana cara menggunakan masing-masing alat. Kemudian, petani diminta untuk menggunakan masingmasing opsi desain alat dan diminta untuk mengisi form penilaian yang sudah disiapkan. Petani diminta untuk memberikan penilaian (persepsi) pada aspek fungsionalitas, efektivitas, ergonomi dan ekonomi alat (Gambar 9) dengan skala 1-5, dimana nilai 5 menunjukkan tingkat penerimaan terbaik.

\subsection{Preferensi Petani pada Alat Tanam Tipe Tugal Dalam}

Pengembangan alat dan mesin pertanian dengan melibatkan preferensi desain dari petani sangat

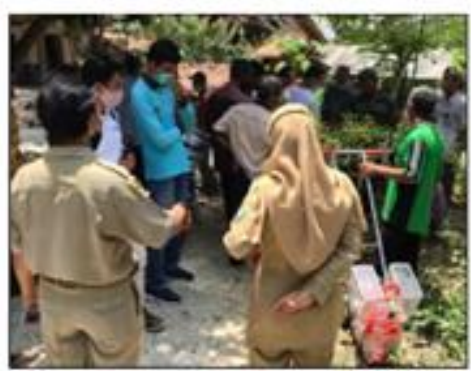

(a)

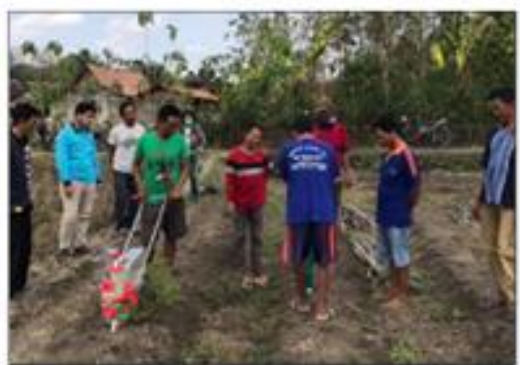

(b)

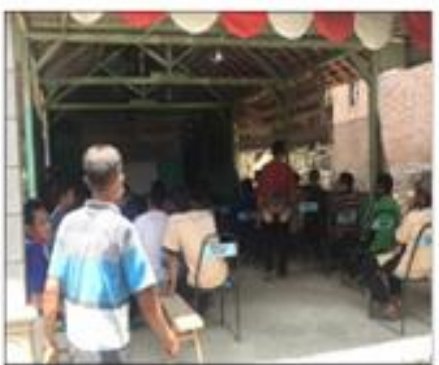

(c)

Gambar 8. Proses Uji Coba dan Demostrasi Prototipe Awal Alat Bersama Petani Jagung di Blora dan Grobogan

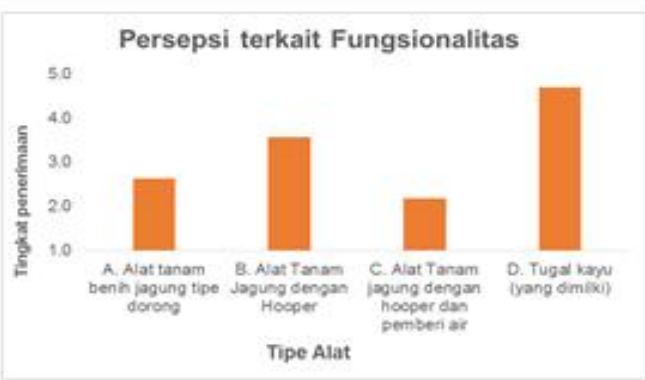

(a)

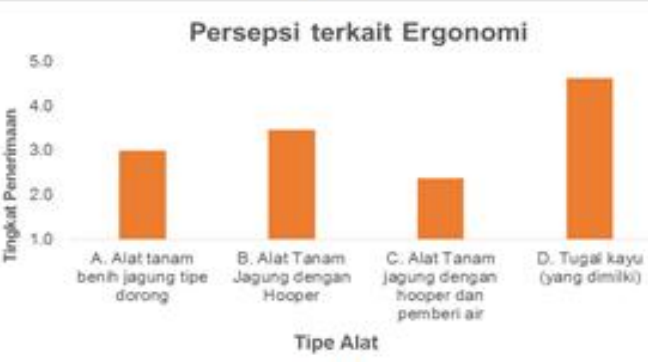

(c)

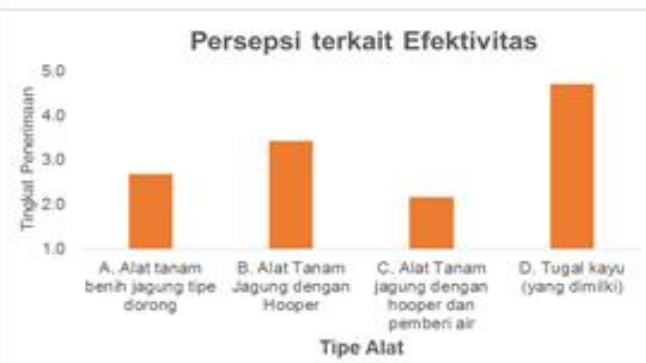

(b)

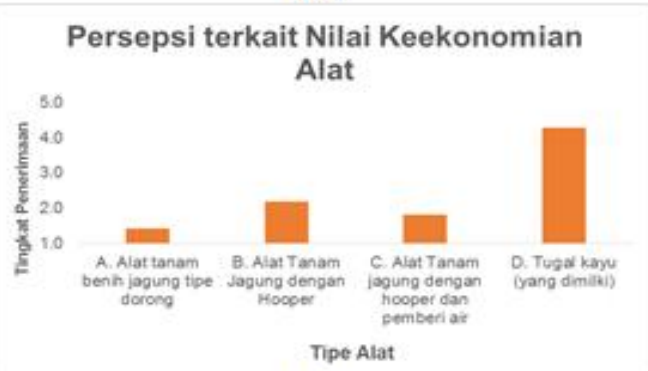

(d)

Gambar 9. Persepsi Petani pada Opsi Desain Alat Tanam yang Ditawarkan 
penting dilakukan supaya alat yang dikembangkan dapat tepat guna dan sesuai dengan kebutuhan petani. Pada penelitian ini, pendekatan kansei engineering digunakan untuk mendapatkan preferensi desain yang diinginkan petani untuk penanaman benih pada musim kemarau. Dari Gambar 9 terlihat bahwa pada aspek fungsionalitas, alat tanam dengan hooper benih lebih disukai karena mudah dioperasikan dan ringan dibawa. Terkait aspek efektivitas, alat tanam dengan hooper benih juga dianggap lebih efektif digunakan untuk menanam benih karena dapat menanam benih dengan sekali proses (tancap). Begitu juga pada aspek ergonomi dan ekonomi alat. Untuk alat tanam tipe dorong, petani menganggap bahwa alat ini tidak efektif untuk penanaman di lahan kering karena mata tugal yang tidak mampu menembus permukaan tanah yang relative keras. Namun, aspek kecepatan menggunakan alat ini disukai oleh petani. Pada desain alat tanam dengan hooper benih dan kotak air (prototipe awal), petani menganggap bahwa penggunaan alat terlalu lamban dan ukuran kotak air yang terlalu besar dan memberatkan ketika melakukan penanaman. Tapi, petani juga menilai bahwa alat yang dilengkapi dengan kotak air akan sangat bermanfaat untuk penanaman di lahan dengan ketinggian dan kemiringan tertentu terutama di musim kemarau. Sehingga, terlihat bahwa faktor kecepatan penggunaan, kemudahan penggunaan, harga yang terjangkau, ringan ketika dibawa, dan memiliki kotak air adalah beberapa karakteristik yang diinginkan petani untuk desain alat tanam benih pada musim kemarau.

\section{KESIMPULAN}

Pada penelitian ini telah dikembangkan alat tanam tipe tugal dalam yang dapat membantu petani melakukan penanaman pada musim kemarau ketika permukaan tanah mengering dan mengeras serta penggunaan tugal kayu kurang efektif. Alat ini dilengkapi dengan hooper benih dan kotak air yang memungkinkan proses penanaman benih dapat dilakukan secara simultan dalam satu kali proses. Kedalaman penanaman yang lebih dalam memungkinkan petani dapat menanam dengan teknik tugal dalam ketika lapisan permukaan lahan mengering dan bagian di bawah permukaan masih lembab. Dari hasil pengujian laboratorium diperoleh kesimpulan bahwa secara kinerja alat dapat melakukan penanaman dengan kedalaman 15$20 \mathrm{~cm}$ dengan 1 benih/lubang serta pemberian air 180-220 mL/lubang tanam. Dari aspek preferensi petani terhadap desain alat tanam benih jagung, diperoleh bahwa faktor kecepatan penggunaan, kemudahan penggunaan, harga yang terjangkau, ringan ketika dibawa, dan memiliki kotak air adalah beberapa karakteristik yang diinginkan petani untuk desain alat tanam benih pada musim kemarau.

\section{UCAPAN TERIMA KASIH}

Ucapan Terima kasih disampaikan kepada PRISMA yang telah memberikan bantuan pendanaan untuk kegiatan ini dan Bappeda Provinsi Jawa Tengah yang telah memfasilitasi kegiatan survey dan pengujian lapangan. Serta, kepada Departemen Teknik Pertanian dan Biosistem, Fakultas Teknologi Pertanian UGM.

\section{DAFTAR PUSTAKA}

BPS. 2018. Jagung 2015-2018. Retrieved 27/1/ 2021, from Badan Pusat Statistik (BPS) Provinsi Jawa Tengah https:// jateng.bps.go.id/indicator/53/725/1/ jagung.html

FAO. 2001. Crop Water Management-Maize. Retrieved 27/1/2021, from Land and Water Development, FAO www.fao.org

Harimurti, E. F. 2018. Perencanaan Pengembangan Kawasan Budidaya Jagung Untuk Peningkatan Perekonomian Kabupaten Pemalang, Jawa Tengah. Institut Pertanian Bogor, Bogor.

He, X., Ding, Y., Zhang, D., Yang, L., Cui, T., dan Zhong, X. 2019. Development of a variable-rate seeding control system for corn planters part II: Field performance. Computers and Electronics in Agriculture, 162:309-317. doi:https://doi.org/ 10.1016/j.compag.2019.04.010 
He, X., Zaiman, W., Xiwen, L., Xiaoman, C., Chunbo, L., dan Ying, Z. 2017. General Structure Design and Field Experiment of Pneumatic Rica Direct-Seeder. International Journal of Agriculture \& Biological Engineering, 10(6): 31-42.

Jindo, T. dan Hirasago, K. 1997. Application studies to car interior of Kansei engine. International Journal of Industrial Ergonomics, 19: 105-114. doi:https:// doi.org/10.1016/S0169-8141(96)000078

Kosky, P., Wise, G., Balmer, R., dan Keat, W. 2010. Exploring engineering : an introduction to engineering and design. London: Academic Press Elsivier.

Kusuma, D., Faiz, A. H., Purba, R. D. A., dan Sabit, M. I. 2018. Perancangan Alat Tanam Benih Ergonomis dengan Pendekatan Antropometri. Paper presented at the Prosiding Industrial Engineering National Conference (IENACO), Sleman, Yogyakarta. http://hdl.handle.net/11617/9764

Luftansa, P. dan Suryadi, A. 2020. Perancangan Alat Penanam Benih Jagung dengan Metode Design for Assembly (DFA). JUMINTEN: Jurnal Manajemen Industri \& Teknologi,1(6):122-132. doi:https:// doi.org/10.33005/juminten.v1i6.197

Ospina-Bayona, H. E., Sanches-Torres, C. C., GarciaLeon, R. A., Ballesteros-Ruiz, H. A., dan Perez-Lorenzo, B. C. 2019. Design of Mechanical Seeder. Journal of Physics:
Conference Series, 1388: 1-7. doi:https:// doi.org/10.1088/1742-6596/1388/1/ 012004

Ritung, S., Nugroho, K., Mulyani, A., dan Suryani, E. 2011. Petunjuk Teknis Evaluasi Lahan Untuk Komoditas Pertanian (Edisi Revisi ed.). Bogor: Balai Besar Penelitian dan Pengembangan Sumberdaya Lahan Pertanian Badan Penelitian dan Pengembangan Pertanian, Kementerian Pertanian.

Sianipar, T. P. O., dan Fatoni, Z. 2019. Perancangan Alat Penanam Benih Jagung dan Penyiraman. Turbulen: Jurnal Teknik Mesin, 2(1): 25-32.

Smith, H. P. 1990. Mesin dan Peralatan Usaha Tani. Yogyakarta: Gadjah Mada University Press.

Sunanto. 2013. Kajian Sebaran Lahan Pertanian Tanaman Pangan Berkelanjutan Di Kabupaten Grobogan. Journal of Rural and Development, IV(1): 43-59.

Syafa'at, I. dan Subantoro. 2017. Perancangan Alat Penanam Benih Jagung Multifungsi Bagi Masyarakat Singorojo, Kendal. Abdimas Unwahas, 2(2): 40-44. doi:http:/ /dx.doi.org/10.31942/abd.v2i2.2104

Yusianto, R. 2012. Rancang Bangun Alat Tanam Benih Jagung Ergonomis Dengan Tuas Pengungkit. Paper presented at the Seminar Nasional Teknologi Informasi \& Komunikasi Terapan, Semarang. 